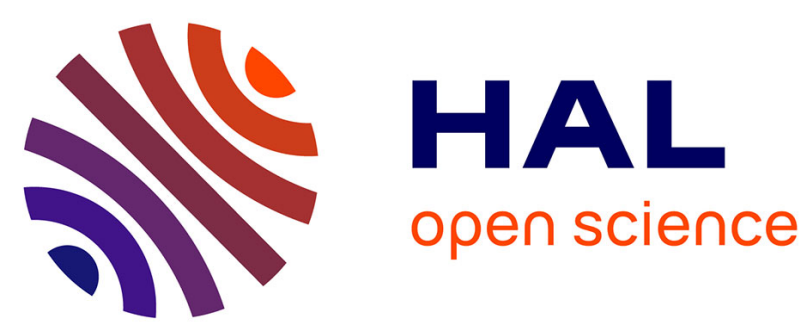

\title{
Pesticide bioaccumulation in epilithic biofilms as a biomarker of agricultural activities in a representative watershed
}

\author{
Danilo Rheinheimer dos Santos, José Augusto Monteiro de Castro Lima, \\ Jocelina Paranhos Rosa de Vargas, Marilia Camotti Bastos, Maria Alice \\ Santanna dos Santos, Leslie Mondamert, Jérôme Labanowski
}

\section{To cite this version:}

Danilo Rheinheimer dos Santos, José Augusto Monteiro de Castro Lima, Jocelina Paranhos Rosa de Vargas, Marilia Camotti Bastos, Maria Alice Santanna dos Santos, et al.. Pesticide bioaccumulation in epilithic biofilms as a biomarker of agricultural activities in a representative watershed. Environmental Monitoring and Assessment, 2020, 192 (6), 10.1007/s10661-020-08264-8 . hal-03089856

\section{HAL Id: hal-03089856 https://hal.science/hal-03089856}

Submitted on 28 Dec 2020

HAL is a multi-disciplinary open access archive for the deposit and dissemination of scientific research documents, whether they are published or not. The documents may come from teaching and research institutions in France or abroad, or from public or private research centers.
L'archive ouverte pluridisciplinaire HAL, est destinée au dépôt et à la diffusion de documents scientifiques de niveau recherche, publiés ou non, émanant des établissements d'enseignement et de recherche français ou étrangers, des laboratoires publics ou privés. 


\section{Title:}

2 Pesticide bioaccumulation in epilithic biofilms as a biomarker of agricultural activities in a

3 representative watershed

4 Journal name:

5 Environmental Monitoring and Assessment

6

\section{Author names:}

8 Danilo Rheinheimer dos Santos, José Augusto Monteiro de Castro Lima, Jocelina Paranhos Rosa de 9 Vargas, Marilia Camotti Bastos, Maria Alice Santanna dos Santos, Leslie Mondamert, Jérôme 10 Labanowski

\section{Corresponding author:}

13 Jocelina Paranhos Rosa de Vargas, Universidade Federal de Santa Maria. Av. Roraima ${ }^{\circ} 1000$. 14 Cidade Universitária, Bairro Camobi. Centro de Ciências Rurais, Prédio 42, Departamento de Solos, 15 Santa Maria - Rio Grande do Sul, Brazil. CEP: 97105-900. Tel: +55 28999298309 E-mail: 16 jocelinaparanhos@mail.ufsm.br 
19 Watershed

\section{Abstract}

Brazil is one of the largest consumers of pesticides in the world. The high rainfall rate and inadequate soil use and management promote the transfer of these compounds to the aquatic system. The aim of this study was to identify and quantify pesticides present in epilithic biofilms in order to evaluate the effectiveness of this matrix as a bioindicator able to discriminate areas and periods with different inputs of pesticides. Among the 25 pesticides analyzed in the biofilms, 20 compounds were detected. The epilithic biofilms picked up pesticides independent of their polarities, even in the period of lower use. The frequency and median concentration of five herbicides (2,4-D, atrazine, desethyl-atrazine, simazine, nicosulfuron), three fungicides (carbendazim, epoxiconazole, tebuconazole), and one insecticide (imidacloprid) were highest in biofilms sampled in summer crops during the growing period. Biofilms collected in the upper region of the catchment, where genetically modified soybean and corn cultivated in a no-tillage system prevail, the highest frequency and median concentration of three herbicides (2,4-D, thifensulfuron, isoproturon), four fungicides (carbendazim, epoxiconazole, tebuconazole, metconazole), and one insecticide (imidacloprid) were observed. Despite the excessive amounts of pesticides used in the catchment, the median values of all pesticides in the epilithic biofilm were considered low. The lower diversity and concentration of pesticides observed in the autumn/winter season is representative of lower use of pesticides, barriers to pesticide transfer from soil to water, and the biofilm's resilience capacity to decompose pesticides.

Key-words: contamination; soil use management; soil erosion; runoff; riparian forest. 
As elsewhere in the world, the model of Brazilian agriculture is based on the production and export of major crops such as soybean, corn, cotton, citrus, and coffee (Graminha et al. 2008). The availability of genetically modified seeds, advanced agricultural machinery, intensive usage of fertilizers and pesticides, and management of no-till farming led to the consolidation of this agricultural model. A problem affecting most of the producing countries is the increase in pesticide use, resulting in an increase in the augmentation of pesticide use per area of cropland from $1.5 \mathrm{~kg} \mathrm{ha}^{-1}$ in 1990 to $2.7 \mathrm{~kg} \mathrm{ha}^{-1}$ in 2016 (FAO, 2018). Based on these values, it is assumed that a significant part of the pesticides applied to the cultures (active compounds and metabolites) are not achieving their primary targets or are not being metabolized by plants.

Nowadays, environmental contamination with pesticides has received great scientific and societal attention due to the major risk posed to the natural environment and human health (Özkara et al. 2016; Tang et al. 2018). The occurrence of various contaminants in the surface water is correlated with agricultural activities, exhibiting the conflict between productivity and contamination (Bastos et al. 2018; Fernandes et al. 2019; Kaiser et al. 2015; Zafar et al. 2016). Pesticide residues can be transferred to water sources by soil erosion, surface runoff, and percolation. These losses are related to low-quality no-tillage management (Tiecher et al. 2017a), the withdrawal of the terraces, and a deficient supply of straw, leading to high loss rates of water, soil (Deuschle et al. 2019), and nutrients (Zafar et al. 2016).

The transfer of pesticides to aquatic ecosystems occurs mainly in diffuse form, that is, most of it is originated by the transport system, in this case, mainly rainwater transport carrying contaminated soil particles; therefore, pesticide residues are divided between the aqueous phase and adsorbent matrix eroded from the soil (Vryzas et al. 2018), depending on their physicochemical properties (aqueous solubility $S_{\mathrm{W}}$, octanol-water partition coefficient $K_{\mathrm{OW}}$, vapor pressure $P$, Henry's law constant $H$, octanol-air partition coefficient $K_{\mathrm{OA}}$, octanol solubility $S_{\mathrm{O}}$ (Shen and Wania 2005). In water, these compounds are present in low concentrations ( $\mu \mathrm{g} \mathrm{\textrm {L } ^ { - 1 }}$ to $\mathrm{ng}$ $\mathrm{L}^{-1}$ ), making it difficult for the monitoring process to perform active sampling. Once in the aquatic ecosystem, the relations between the pesticides found in soluble form and those adsorbed to a given matrix can change in the face of new geochemical and biological conditions in the environment. An example are the epilithic biofilms, which can interact with pesticides by adsorbing soluble compounds or incorporating contaminated sediments in its extracellular polymeric matrix (Battin et al. 2016; Lawrence et al. 2001). 

attached), a diversity of autotrophic and heterotrophic microorganisms (bacteria, algae, fungi, and microfauna), and detritus exogenous or produced in situ (Flemming and Wingender 2010). Biofilms are of fundamental ecological importance in the aquatic ecosystem because their water/substrate interface is an autotrophic primary producer, an organic matter decomposer, and an adsorption/desorption reactor (Feckler et al. 2015). Biofilms have a high physicochemical reactivity due to the great diversity of surface functional groups, such as amine, amide, carboxyl, and phenolic in organic matrixes provided by organic constituents, as well as a permanent charge and surface hydroxyl sites in clay minerals and oxides in the inorganic colloid matrix provided by the inorganic constituents (Essington 2005; Fernandes et al. 2019). Proia et al. (2013) have shown that microorganisms in biofilms have a short life cycle and there is a strong interaction between the microbiota. Due to these characteristics, biofilms can be used as a powerful ecological indicator (Edwards and Kjellerup 2013; Sabater et al. 2007) because the availability of diverse sorption sites and their likely saturation contribute to multiple kinetics of bioaccumulation, being consecutive or stationary (Zhang et al. 2018).

In areas of intense agriculture, aquatic ecosystems and food webs are exposed to pesticides that alter species abundance and diversity, causing negative effects even at low concentrations (Beketov et al. 2013). When exposed to this type of contamination, the photosynthetic activity of biofilms can decrease, and inhibition of growth and changes in community structure can be observed (Kim et al. 2016; Pesce et al. 2012). For example, Bricheux et al. (2013) showed that by exposing biofilms to glyphosate and diuron, the growth of the autotrophic community was inhibited, and the bacterial communities adapted by changing their composition. In addition, areas with water collection for drinking water distribution may be contaminated, presenting a risk to the population if the treatment is inefficient for the removal of these organic compounds from the water (Beketov et al. 2013). Previous studies in the Guaporé catchment showed that bioaccumulation in epilithic biofilms could be used as biomarkers of anthropic contamination by glyphosate and its metabolite AMPA (Fernandes et al. 2019) and by carbamazepine and sucralose (Bastos et al. 2018). This study aimed at identifying and quantifying pesticides present in epilithic biofilms in order to evaluate the effectiveness of this matrix as a bioindicator capable of discriminating areas and periods with different inputs of pesticides. 
Catchment description

102

Located in the state of Rio Grande do Sul, southern Brazil, the Guaporé River catchment drains an area

104 of 2,490 $\mathrm{km}^{2}$ and is $153 \mathrm{~km}$ long (Lima et al. 2020). Classified as Cfa in the Köppen system, the climate is characterized by an average annual temperature of $17.9^{\circ} \mathrm{C}$ and an average annual minimum and maximum temperatures of 12.6 and $24.7{ }^{\circ} \mathrm{C}$, respectively. In this catchment, previous studies revealed that rain events have

107 high erosion potential (8,800 MJ mm ha ${ }^{-1} \mathrm{~h}^{-1}$ year $\left.^{-1}\right)$ (Didoné et al. 2014) with greater occurrence from July through November (INMET 2019). Sediment production in 2012 amounted to $390.2 \mathrm{Mg} \mathrm{km}^{-2}$ year $^{-1}$, and the average was estimated at $140 \mathrm{mg} \mathrm{km}^{-2}$ year $^{-1}$ from 2000 to 2010, with a runoff coefficient of up to $31 \%$ (Didoné et al. 2014). The land use in this area is dominated by cropland (60.0\%), natural forest (30.1\%), pastureland 111 (5.6\%), forestry (3.1\%), urban areas (0.6\%), and water bodies (0.4\%) (Fig. 1) characteristic of rural areas with 112 high production in southern Brazil. In the upper third of the catchment, the relief is nearly level to gently sloping 113 and predominated by Ferralsols; the no-tillage system has been adopted and has predominated for two decades. 


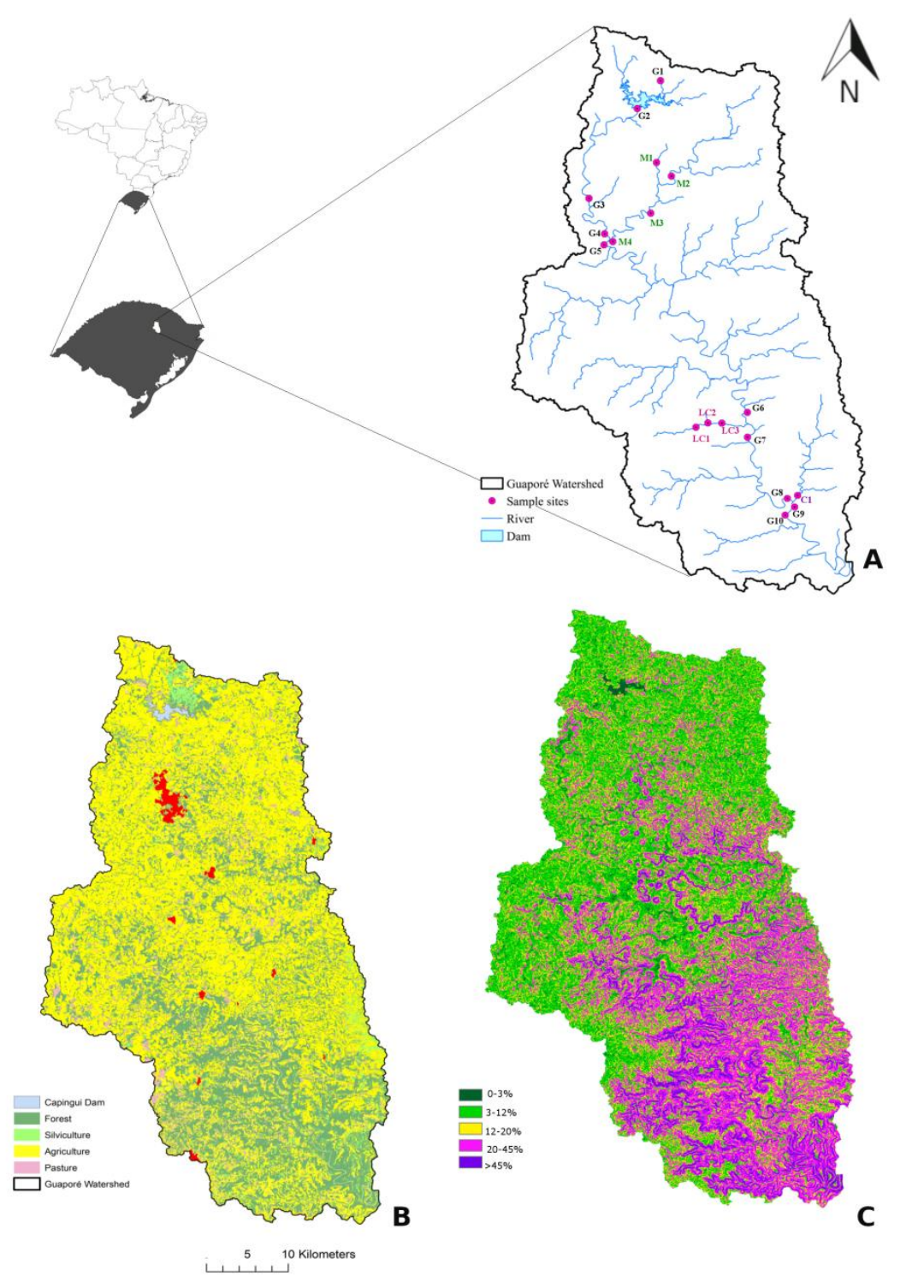

Fig 1 - Characteristics of area and location of the sampling sites in the Guaporé River and its tributaries:(a) location of the sampling sites in the Guaporé watershed, (b) Guaporé watershed land use and (c) Guaporé watershed slopes. (RS - Brazil).

Besides soybean (Glycine max L. Merr.) cultivation, livestock, swine, and poultry are also produced in the catchment in spring/summer. The animals reside in marginal noncultivated areas, generally along the watercourses. The pesticides used are characterized by high doses of herbicides and fungicides applied to soybean production, including 2,4-D for plants resistant to glyphosate. The annual production density of this region is $161.6 \mathrm{mg} \mathrm{year}^{-1} \mathrm{~km}^{-2}$ of soybean; 41.5 and $148.2 \mathrm{mg} \mathrm{year}^{-1} \mathrm{~km}^{-2}$ of corn and corn silage respectively; and 0.3 and $1.3 \mathrm{mg}$ year ${ }^{-1} \mathrm{~km}^{-2}$ of tobacco and yerba mate, respectively. In the other two-thirds (middle and lower parts) of the catchment, land use is more diverse and conventional soil management predominates in shallow soils with a rocky surface (Luvisols, Acrisols, and Regosols). The cultivated surface is imbricated in 
126 landscape and the family farmers have less than 10 ha. The annual production density of this region is $38.1 \mathrm{mg}$

127 year ${ }^{-1} \mathrm{~km}^{-2}$ of soybean; 53.4 and $233.1 \mathrm{mg}$ year ${ }^{-1} \mathrm{~km}^{-2}$ of corn and corn silage, respectively; 3.5 and $34.1 \mathrm{mg}$ 128 year ${ }^{-1} \mathrm{~km}^{-2}$ of tobacco and yerba mate, respectively (IBGE, 2019).

129

130 Sampling sites

131

A total of 18 sampling sites were selected, which were located in Guaporé River (G1, G2, G3, G4, G5,

133 G6, G7, G8, G9, and G10), in the tributary of the Marau Stream (M1, M2, M3, and M4), Lajeado Carazinho 134 Stream Tributary (LC1, LC2, and LC3) and the tributary of the Carazinho Stream (C). Descriptions of each site 135 and locations are shown in Table 1 and Figure 1, respectively. 


\begin{tabular}{|c|c|c|c|c|c|c|c|c|c|}
\hline \multirow[t]{2}{*}{ Sample sites } & \multicolumn{8}{|c|}{ Upper Region } & \multirow[b]{2}{*}{ M4 } \\
\hline & G1 & G2 & G3 & G4 & G5 & M1 & M2 & M3 & \\
\hline Catchment area $\left(\mathrm{km}^{2}\right)$ & 1.3 & 123 & 201 & 267 & 542 & 13.4 & 165 & 227 & 256 \\
\hline \multirow[t]{2}{*}{ Distance $(\mathrm{km})$} & 0 & 6 & 23 & 32 & 35 & - & 0 & 10 & 23 \\
\hline & \multicolumn{8}{|c|}{ Land use (\%) } & \\
\hline Forest & 100 & 28 & 24 & 23 & 22 & 22 & 20 & 21 & 22 \\
\hline Agriculture & 0 & 64 & 69 & 71 & 70 & 72 & 74 & 72 & 72 \\
\hline \multirow[t]{2}{*}{ Width riparian forest } & $>800$ & $15-60$ & 15 & 15 & 15 & 15 & 15 & 15 & 15 \\
\hline & \multicolumn{9}{|c|}{ Slope class (\%) } \\
\hline $0-3 \%$ & 5 & 10 & 9 & 8 & 7 & 6 & 7 & 6 & 6 \\
\hline $3.1-12 \%$ & 49 & 60 & 59 & 58 & 57 & 56 & 60 & 57 & 56 \\
\hline $12.1-20 \%$ & 35 & 22 & 23 & 23 & 24 & 25 & 23 & 24 & 24 \\
\hline $20.1-45 \%$ & 12 & 8 & 9 & 10 & 11 & 13 & 9 & 12 & 13 \\
\hline \multirow[t]{2}{*}{$>45 \%$} & 0 & 0 & 0 & 0 & 1 & 0 & 0 & 1 & 1 \\
\hline & \multicolumn{8}{|c|}{ Middle/Lower Region } & \\
\hline Sample sites & G6 & G7 & G8 & G9 & G10 & LC1 & LC2 & LC3 & $\mathrm{C}$ \\
\hline Catchment area $\left(\mathrm{km}^{2}\right)$ & 1442 & 1505 & 1697 & 1850 & 1853 & 30 & 3.2 & 39 & 144 \\
\hline \multirow[t]{2}{*}{ Distance $(\mathrm{km})$} & 85 & 90 & 106 & 108 & 110 & 0 & - & 3.2 & 0 \\
\hline & \multicolumn{8}{|c|}{ Land use (\%) } & \\
\hline Forest & 27 & 28 & 31 & 32 & 32 & 50 & 61 & 52 & 46 \\
\hline Agriculture & 67 & 66 & 62 & 61 & 61 & 42 & 32 & 40 & 50 \\
\hline \multirow[t]{2}{*}{ Width riparian forest } & 15 & $>60$ & $>100$ & $>100$ & $>100$ & $>100$ & 15 & $>100$ & $>100$ \\
\hline & \multicolumn{9}{|c|}{ Slope class (\%) } \\
\hline $0-3 \%$ & 6 & 5 & 5 & 5 & 5 & 4 & 1 & 3 & 2 \\
\hline $3.1-12 \%$ & 47 & 45 & 42 & 41 & 41 & 34 & 10 & 28 & 23 \\
\hline $12.1-20 \%$ & 24 & 24 & 23 & 23 & 23 & 24 & 20 & 22 & 27 \\
\hline $20.1-45 \%$ & 21 & 22 & 24 & 26 & 26 & 29 & 53 & 34 & 43 \\
\hline$>45 \%$ & 3 & 4 & 5 & 5 & 5 & 10 & 17 & 14 & 5 \\
\hline
\end{tabular}

138 Table 1 - Catchment area, land use and slope class at the different sampling sites in the Guaporé

139 River and its tributaries.

140

141 Biofilm sampling

142

The first biofilm sampling campaign was conducted between 11 and 13 December 2014 spring/summer

144 season), two days after a high precipitation event $89 \mathrm{~mm}$ (INMET 2019). By this time, the soybean crop was in

145 V3 stage, the corn was in R1 stage, and the first leaves of flue-cured tobacco were harvested. The second biofilm

146 sampling campaign was performed between 3 and 5 June 2015 (autumn/winter season); it registered $4 \mathrm{~mm}$ of

147 precipitation during the preceding week. During this period, less than one-fifth of the total agricultural surface

148 was cultivated with wheat, barley, and winter grassland forage. The rate of pesticide application was low

149 compared to that of the spring/summer season (Fig. 2, data obtained from farmers). 


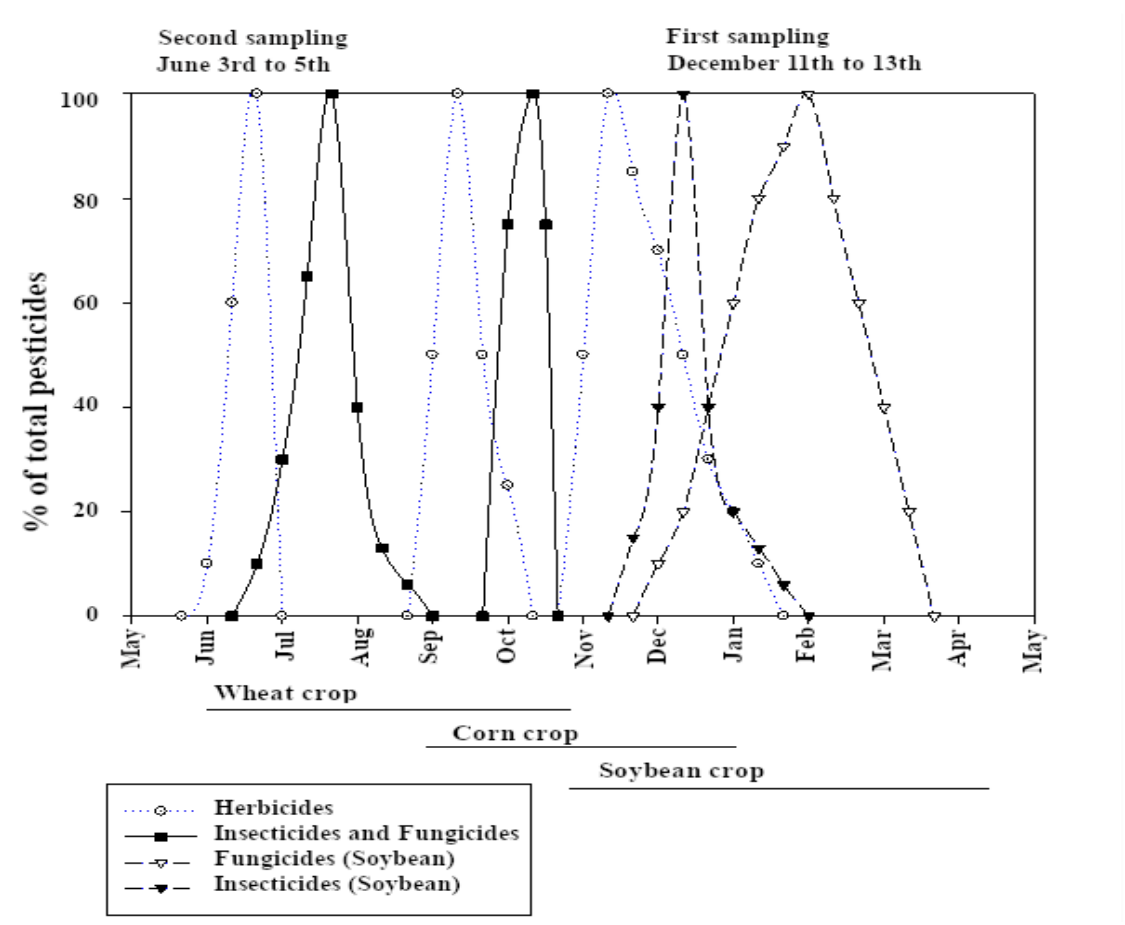

\section{1}

Fig 2 - Relationship between the period of the year and the intensity of pesticide applied in wheat, corn and soy crops in the Guaporé watershed.

At each collection site, epilithic biofilms were obtained from submerged rocks with the aid of toothbrushes. The rock adhered material was washed with deionized water and recuperated in glass jars. The detailed sampling procedure has been published by Bastos et al. (2018).

The pesticides were selected according to the Brazilian registered agricultural compounds and with field investigations. Subsequently, a second selection was made according to the operational and methodological capacity of the laboratories involved.

The selected molecules and their physicochemical properties are presented in the appendix (Table A1). Sampling points were selected in order to represent two macro-regions in the river basin, north and south regions, which are contrasting in terms of relief, land use, and agricultural management aspects.

Analytical procedure

In the laboratory, glass jars with biofilms were transferred to individual high-density polyethylene jars and frozen at $-80{ }^{\circ} \mathrm{C}$ for subsequent lyophilization. After being freeze-dried, samples were homogenized in an agate mortar to obtain a representative sample for analysis. The biofilm extraction procedure was performed using an adapted method from Jelić et al. (2009) that is well described by Aubertheau et al. (2017). Five hundred 
milligrams of biofilm were extracted by accelerated solvent extraction equipment (ASE ${ }^{\mathrm{TM}} 350$, Thermo Fisher Scientific Inc., Waltham, USA) at $80{ }^{\circ} \mathrm{C}$ using methanol/water $(1 / 2, \mathrm{v} / \mathrm{v})$ as the extraction solvent. The extracts were purified by solid-phase extraction (Autotrace ${ }^{\mathrm{TM}} 150$, Thermo Scientific, 125 Waltham, USA) using Oasis $®$ HLB cartridges ( $6 \mathrm{cc}, 200 \mathrm{mg}$ of sorbent, Waters, Milford, USA) with methanol as eluent. The extracts obtained by the Solid Phase Extraction (SPE) system were evaporated under $N_{2}$ flow for restitution to $500 \mu$ with a methanol/water mixture $(10 / 90, \mathrm{v} / \mathrm{v})$. The recovered liquid was then filtered one last time using Mini-Uniprep ${ }^{\mathrm{TM}}$ filters (PVDF Filter Media with polypropylene housing, pore size $0.45 \mu \mathrm{m}$, Durapore ${ }^{\circledR}$, Millipore, Billerica, USA). Each biofilm sample was analyzed twice with triplicate measurements.

The identification and quantification of the molecules were performed by ultra-high performance liquid chromatography (Thermo Fisher Scientific, Waltham, USA), coupled to a time-of-flight mass spectrometry (Impact II ${ }^{\mathrm{TM}}$ model, Bruker Daltonics, Billerica, USA) using the method Pesticide Screener (developed by Thermo Fisher Scientific, Waltham, USA). For each extract, there were three injections of $20 \mu \mathrm{L}$ in positive and negative ionization mode. Data processing was performed using Compass Data Analysis 4.2 and Target Analysis software (Bruker, Billerica, USA).

The concentration of pesticides in biofilms was determined by adjusting the linear model used between the concentration of the standards and the peak area of each injection for each compound detected. Validation of the method was followed by the French norm NF XP T90-210 carried out through linearity, repeatability, and Cochran's test (more details on the methodology available in Lima et al. 2020). The limits of detection (LD) ranged from 0.5 to $1 \mathrm{ng} / \mathrm{g}$. The $\mathrm{LD}$ and limit of quantification LQ were estimated from the background noise. In this case, the LD and LQ were calculated by determining the maximum amplitude of the signal over a distance equal to 20 times the width at mid-height of the peak corresponding to the compound searched, and these values were used in the statistical analysis. A total of 25 compounds were analyzed, namely: 2,4-D, atrazine, boscalid, carbendazim, chlorotoluron, chlorpyrifos-ethyl, cypermethrin, deltamethrin, desethyl-atrazine, dicamba, epoxiconazole, imidacloprid, iodosulfuron-methyl-sodium, isoproturon, MCPA, mesotrione, mesosulfuronmethyl, metconazole, nicosulfuron, prochloraz, prosulfuron, prothioconazole, simazine, tebuconazole, and thifensulfuron-methyl.

The methodology description for method validation and the physico-chemical properties of the pesticides studied are available in the appendixes of this work (A1, A2 and A3). 

pesticides exhibited a normal distribution. Because the results did not show normal distribution, the median was used as a measure of position, and the upper and lower quartiles, interquartile range, and maximum and minimum values were used as dispersion measures. The hypothesis that the epilithic biofilms could discriminate spatial and temporal flux of pesticides from soil to aquatic ecosystems was statistically evaluated by the MannWhitney $U$ nonparametric test. The STATISTICA 7.0 program was used to carry out statistical procedures.

\section{Results and Discussion}

Occurrence and concentration

Only five pesticides (cypermethrin, deltamethrin, dicamba, iodosulfuron-methyl, and MCPA) were not detected in the epilithic biofilms sampled in the Guaporé River and its tributaries. The absence of these compounds in biofilms is not proof that these compounds are not being used in agricultural fields and does not refute the possibility that the functional groups of biofilms may not have affinity with pesticides. However, the fieldwork carried out by our team demonstrates that, in this region, the use of pyrethroid insecticides is being replaced by systemic compounds, in particular imidacloprid and other neonicotinoid pesticides. In southern Brazil, pyrethroid is still used in urban sprayings and in fruit production. In addition, the herbicide dicamba is used in combination with genetically modified soybean varieties (Xtend $\left.{ }^{\circledR}\right)$ that have not yet been cultivated in Brazil. Some farmers in the Guaporé catchment use these pesticides for controlling plants resistant to glyphosate. The last two non-detected herbicides were recommended for dicotyledonous control in corn and cereal production, but they are rarely used this catchment (data obtained from farmers). $\mathrm{D}$, atrazine, and simazine), and one metabolite (desethyl-atrazine), three fungicides (carbendazim, tebuconazole, and epoxiconazole), and two insecticides (imidacloprid and chlorpyrifos-ethyl). In addition, another seven herbicides ( 25 to $81 \%$ frequency) and four fungicides (6 to $69 \%$ frequency) were detected in biofilms occurring in both the Guaporé River and in three of its main tributaries. In autumn/winter season, only two pesticides were found at $100 \%$ of the sites monitored (2,4-D and carbendazim), but all 20 compounds were quantified in biofilms with frequency ranging from $22 \%$ (thifensulfuron-methyl) to $83 \%$ (atrazine and tebuconazole, Table 2). Some 
studies have demonstrated that the highest levels of pesticides in surface water occur as pulses in response to late spring and early summer rainfall events (Pascual Aguilar et al. 2017; Pérez et al. 2017; Rabiet et al. 2010); the same was observed in biofilms in the present study.

The frequency of pesticide detection in biofilms is consistent with their consumption in Brazil and consequently, with use in the Guapore catchment. Over the last few years, Brazilian farmers used $5.8 \times 10^{7} \mathrm{Mg}$ of 2,4-D, $2.5 \times 10^{7} \mathrm{Mg}$ of atrazine, $9.4 \times 10^{6} \mathrm{Mg}$ of imidacloprid, and $6.5 \times 10^{6} \mathrm{Mg}$ of chlorpyrifos-ethyl (IBAMA 2018). The three most frequently detected fungicides in biofilms are also the most widely used in

Brazil (tebuconazole, carbendazim, and epoxiconazole, with 4.5, 3.7, and $0.8 \times 10^{6} \mathrm{mg}$, respectively).

\begin{tabular}{|c|c|c|c|c|c|c|}
\hline \multirow{2}{*}{ Pesticide } & \multicolumn{3}{|c|}{11 to 13 December } & \multicolumn{3}{|c|}{3 to 5 June } \\
\hline & $\begin{array}{l}\text { Frequency } \\
(\%)\end{array}$ & $\begin{array}{l}\mathbf{I Q R} \\
\left(\mathrm{ng} \mathrm{g}^{-1}\right)\end{array}$ & $\begin{array}{l}\mathrm{IQR}^{\mathrm{I}} \\
(\%)\end{array}$ & $\begin{array}{l}\text { Frequency } \\
(\%)\end{array}$ & $\begin{array}{l}\mathbf{I Q R} \\
\left(\mathrm{ng} \mathrm{g}^{-1}\right)\end{array}$ & $\begin{array}{l}\text { IQR } \\
(\%)\end{array}$ \\
\hline \multicolumn{7}{|l|}{ Herbicides } \\
\hline $2,4-d$ & 100 & 9.1 & 162 & 100 & 1.7 & 348 \\
\hline Atrazine & 100 & 60.3 & 159 & 83 & 0.8 & 159 \\
\hline Desethyl-atrazine & 100 & 8.7 & 67 & 78 & 3.5 & 698 \\
\hline Simazine & 100 & 30.7 & 231 & 72 & 1.9 & 374 \\
\hline Nicosulfuron & 81 & 0 & 0 & 39 & 0.5 & 0 \\
\hline Mesosulfuron-methyl & 50 & 0.5 & 200 & 28 & 0.5 & 0 \\
\hline Chlorotoluron & 50 & 0.5 & 200 & 28 & 0.5 & 0 \\
\hline Prosulfuron & 44 & 0.5 & 0 & 39 & 0.5 & 0 \\
\hline Mesotrione & 38 & 0.5 & 0 & 61 & 0.5 & 100 \\
\hline Thifensulfuron-methyl & 25 & 0.4 & 0 & 33 & 0.5 & 0 \\
\hline Isoproturon & 31 & 0.5 & 0 & 22 & 0.1 & 0 \\
\hline Dicamba & 0 & 0 & 0 & 0 & 0 & 0 \\
\hline Iodosulfuron-methyl & 0 & 0 & 0 & 0 & 0 & 0 \\
\hline MCPA & 0 & 0 & 0 & 0 & 0 & 0 \\
\hline \multicolumn{7}{|l|}{ Fungicides } \\
\hline Carbendazim & 100 & 22.6 & 90 & 100 & 9.6 & 205 \\
\hline Epoxiconazole & 100 & 3.0 & 89 & 78 & 0.7 & 132 \\
\hline Tebuconazole & 100 & 4.4 & 229 & 83 & 1.5 & 299 \\
\hline Metconazole & 69 & 0.5 & 100 & 56 & 0.5 & 100 \\
\hline Prochloraz & 56 & 0.5 & 100 & 50 & 0.5 & 200 \\
\hline Prothioconazole & 56 & 0.5 & 100 & 56 & 0.5 & 100 \\
\hline Boscalid & 6 & 0 & 0 & 33 & 0.5 & 0 \\
\hline \multicolumn{7}{|l|}{ Insecticides } \\
\hline Imidacloprid & 100 & 17.0 & 272 & 67 & 3.0 & 292 \\
\hline Chlorpyrifos-ethyl & 100 & 0 & 0 & 78 & 0.1 & 25 \\
\hline Cypermethrin & 0 & 0 & 0 & 0 & 0 & 0 \\
\hline Deltamethrin & 0 & 0 & 0 & 0 & 0 & 0 \\
\hline
\end{tabular}

Table 2 - Frequency of pesticide detection (\%) and inter-quartile interval (median and \%) in epilithic biofilms 
243 2,4-D, atrazine, desethyl-atrazine, and simazine, respectively. The highest concentrations of insecticides were

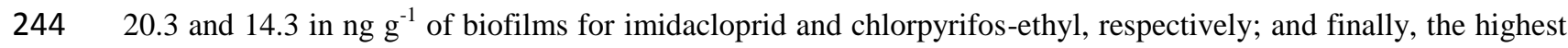

245 concentrations of fungicides in biofilms were 73.0, 44.6, and $35.9 \mathrm{ng} \mathrm{g}^{-1}$ of biofilms for carbendazim,

246 epoxiconazole, and tebuconazole, respectively (Fig. 3). Fifty per cent of the epilithic biofilms sampled had

247 median concentrations varying, in $\mathrm{ng} \mathrm{g}^{-1}$ of biofilms, between 0.5 and 6.0 (2,4-D), 0.5 and 34.0 (atrazine), 0.5

248 and 12.0 (desethyl-atrazine), 0.5 and 10.0 (simazine), 0.5 and 5.0 (imidacloprid), 3.4 to 24.0 (carbendazim), and

2490.5 and 4.0 (epoxiconazole and tebuconazole). Usually, the highest concentration of pesticides in biofilms is in 250 accordance with the highest frequency of detection. High concentrations and loads can also be linked to 251 catchment and climate conditions, where peaks in concentrations are observed in the summer, which is usually a 252 rainy period with conditions known to be linked to high pollutant mobilization (Zhang et al. 2016). 


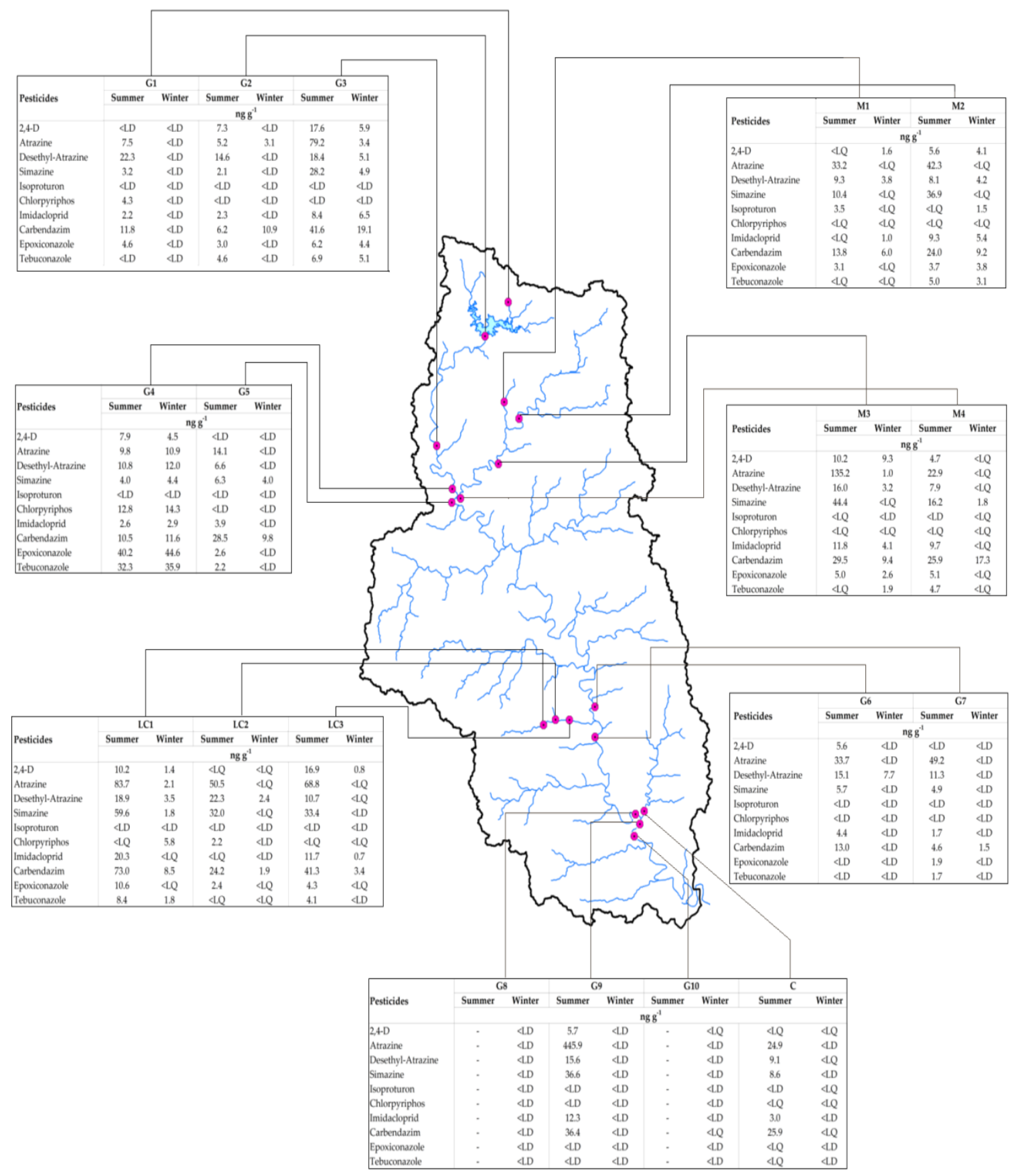

Fig 3 - Spatial and temporal pesticides concentration in biofilms sampled in the Guaporé catchment

Pesticides are from punctual and non-punctual sources and are transported by runoff from agricultural

257 and urban areas, discharge from reservoirs and aquifers, and atmospheric deposition (Pascual Aguilar et al. 2017). They are transported from farmland toward water bodies in various forms including dissolved, sorbed on dissolved organic carbon, and sorbed on suspended or colloidal particles. Pesticides in each phase have different means of transportation and mobility. In particular, sorption on dissolved organic carbon can effectively increase 

properties of pesticides such as water solubility, octanol-water partition coefficient, dissociation (pKa), and Henry's law constant are also determining factors of leaching potential. However, in the case of preferential flow, pesticides can be rapidly transferred to groundwater irrespective of their physicochemical properties. Vryzas (2018) reported higher pesticide concentrations in shallow groundwater from experimental boreholes compared to the concentrations in the adjacent deep groundwater (drinking or irrigation water wells). Mixed leaching mechanisms ("chromatographic" and preferential flow) have been reported by the authors to be involved in the contamination of adjacent aquifers with different water residence times. nonspecific mechanisms (physical adsorption), and by hydrophobic interaction (Barrett and McBride 2007; Kleber et al. 2007; Lawrence et al. 2001; Späth et al. 1998). Additionally, microorganisms and macroinvertebrates can uptake and accumulate pesticides, since they are in constant interaction with biofilms and are sometimes used as a source of nourishment (Rhea et al. 2006). The observed high diversity and frequency of detection of pesticides in the Guaporé catchment showed that biofilms can be used as a powerful ecological indicator of pesticide exposure, as has been proposed by Edwards and Kjellerup (2013).

Spatial sources of pesticide contamination (soil use and management) discrimination of the upper and the middle/lower regions of the Guapore catchment (Table 3). In the upper region, by comparison with other catchment places, biofilms were more impregnated by three herbicides $(2,4-\mathrm{D}$, thifensulfuron-methyl, isoproturon), four fungicides (carbendazim, epoxiconazole, metconazole, tebuconazole), and one insecticide (imidacloprid). In addition, the interquartile range for the atrazine and simazine in the upper region was lower than that found in the middle/lower region. The upper region has a plane relief terrain with low slopes and almost $100 \%$ of the agricultural surface is cultivated on a no-tillage system with soybean and corn genetically modified. Moreover, high hydraulic connectivity between cultivated fields and watercourses was observed. In contrast, although agriculture is performed in a more declivous area and mainly under conventional tillage, the cultivated areas are imbricated in the landscape and the riparian forest is very large in the middle/lower region of the Guaporé watershed in comparison to the upper region (Table 1). 


\begin{tabular}{|c|c|c|c|c|}
\hline Pesticides & $\begin{array}{c}\text { Median } \\
\text { spring/summer } \\
\left(\mathrm{ng} \mathrm{g}^{-1}\right)\end{array}$ & $\begin{array}{c}\text { Median } \\
\text { autumn/winter } \\
\left(\mathrm{ng} \mathrm{g}^{-1}\right)\end{array}$ & $\begin{array}{c}\begin{array}{c}\text { Median } \\
\text { upper } \\
\left(\mathrm{ng} \mathrm{g}^{-1}\right)\end{array} \\
\end{array}$ & $\begin{array}{c}\begin{array}{c}\text { Median } \\
\text { middle/lower }\end{array} \\
\left(\mathrm{ng} \mathrm{g}^{-1}\right)\end{array}$ \\
\hline \multicolumn{5}{|l|}{ Herbicides } \\
\hline 2,4-D & 5.6 & 0.5 & 4.6 & 0.5 \\
\hline Atrazine & 38.0 & 0.5 & 7.5 & 1.3 \\
\hline Desethyl-atrazine & 13.0 & 0.5 & 7.3 & 5.6 \\
\hline Simazine & 13.3 & 0.5 & 4.2 & 1.2 \\
\hline Mesotrione & 0.0 & 0.5 & 0.5 & 0.0 \\
\hline $\begin{array}{l}\text { Mesosulfuron- } \\
\text { methyl }\end{array}$ & 0.3 & 0.0 & 0.3 & 0.0 \\
\hline Nicosulfuron & 0.5 & 0.0 & 0.5 & 0.5 \\
\hline Prosulfuron & 0.0 & 0.0 & 0.0 & 0.0 \\
\hline $\begin{array}{l}\text { Thifensulfuron- } \\
\text { methyl }\end{array}$ & 0.0 & 0.0 & 0.3 & 0.0 \\
\hline Isoproturon & 0.0 & 0.0 & 0.3 & 0.0 \\
\hline Chlorotoluron & 0.3 & 0.0 & 0.0 & 0.0 \\
\hline \multicolumn{5}{|l|}{ Fungicides } \\
\hline Carbendazim & 25.0 & 4.7 & 12.7 & 4.0 \\
\hline Epoxiconazole & 3.4 & 0.5 & 3.4 & 0.5 \\
\hline Metconazole & 0.5 & 0.5 & 0.5 & 0.0 \\
\hline Tebuconazole & 1.9 & 0.5 & 2.6 & 0.5 \\
\hline Prothioconazole & 0.5 & 0.5 & 0.5 & 0.3 \\
\hline Boscalid & 0.0 & 0.0 & 0.0 & 0.0 \\
\hline Prochloraz & 0.5 & 0.3 & 0.5 & 0.0 \\
\hline \multicolumn{5}{|l|}{ Insecticides } \\
\hline Imidacloprid & 4.1 & 0.5 & 3.4 & 0.5 \\
\hline Chlorpyrifos-ethyl & 0.5 & 0.5 & 0.5 & 0.5 \\
\hline
\end{tabular}

291 Table 3 - Medians concentration of pesticides in epilithic biofilms sampled in Guaporé River and its tributaries,

292 according to their sampling period (spring/summer and autumn/hiver) seasons and location (upper and 293 middle/lower).

294 The southern region of Brazil presents a subtropical humid climate with an average annual rainfall 295 between 1,550 and $1,700 \mathrm{~mm}$, but it may even reach 2,500 $\mathrm{mm}$ (INMET 2019). The rain has very high erosion 296 potential (Didoné et al. 2014). Even several decades after the adoption of a no-tillage system, agricultural areas 297 are still the main source of sediments to rivers in the Guaporé catchment (Tiecher et al. 2017a), as well as in other watersheds in the south of Brazil (Tiecher et al. 2018; Tiecher et al. 2017b). In Brazil, the no-tillage system

299 is usually a non-optimal soil management system because farmers removed the terraces, and there is an insufficient amount of straw in the surface of the soil. High rates of water loss, sediment (Deuschle et al., 2019), and nutrients (Zafar et al. 2016) have been observed in the Guaporé catchment. In the no-tillage system, the 

regularity and frequent rainfall occurring in the catchment, there is a constant pesticide wash-off the superficial residues. In fact, under these conditions, it is not possible to produce crops without transferring sediment and agrochemicals to the superficial water resources. There is no doubt that certain amounts of the pesticides used in crops are transferred to water courses. The amount and frequency of pesticides reaching surface water reserves depends on the quantity added, the distribution of crops in the landscape, and the presence of physicalmechanical and/or natural barriers to the transfer of sediment and water by erosion and runoff. pesticides to surface water. Rates of soil erosion, irrigation, precipitation, and half-life are the major factors that govern the transportation of pesticides to the surface water (Aravinna et al. 2017). The compounds with low $\mathrm{K}_{\text {ow }}$ and $\mathrm{K}_{\mathrm{oc}}$, and high mobility were in more variable concentrations in biofilms sampled in spring/summer season (simazine, carbendazim, and imidacloprid). However, pesticides with moderate adsorption capacity in colloids $\left(\mathrm{K}_{\mathrm{ow}} 3.0\right.$ to 5.0, Lewis et al. 2016) were also found in high concentrations in biofilms (tebuconazole, epoxiconazole, and chlorpyrifos-ethyl). Pesticides are transferred from soil to watercourse, mostly in soluble form by runoff from cultivated fields, but also adsorbed by inorganic and organic colloids in eroded sediment. The transport of pesticides through preferential water flow to macropores to tile drainage plays an important role in the rapid transport of pesticides to surface waters (Tang et al. 2012; Vymazal and Březinová 2015). When these pesticides enter the water bodies, desorption from colloids occurs, releasing them to the aqueous phase (Aravinna et al. 2017). The water flow velocity also plays an important role in the accumulation of these compounds in biofilms. Chaumet et al. (2019a) showed higher accumulation of diuron at lower flow velocity compared to the higher flow for raw biofilms. Temporal use of pesticides (application - transfer to watercourse - decomposition - resilience) concentrations of five herbicides (2,4-D, atrazine, desethyl-atrazine, simazine, and nicosulfuron), three fungicides (carbendazim, epoxiconazole, and tebuconazole), and one insecticide (imidacloprid) were higher in the spring/summer than in the autumn/winter season (Table 3, statistical analysis is available in Table A4. These results were coherent with the phase of development of soybean, corn, and tobacco plants and the period of pesticide application. The maximum herbicide consumption occurs from October to December, the period in 
which they are used in pre-sowing and post-emergence of genetically modified soybean and corn (>90\% of herbicides consumption in the Guaporé catchment). Also, although in smaller quantities, herbicides are used in pre-transplantation and during the development of tobacco during the spring/summer season. The fungicides and insecticides were used more intensely between December and February, mainly in soybean and tobacco production (Fig. 2).

After February, pesticide application is reduced drastically in the Guaporé catchment. The tobacco harvest ends in mid-February and many farmers sow corn or silage production, but without the use of fungicide and insecticides. The soybean harvest takes place from mid-March until the end of April. More than $90 \%$ of the agricultural area remains fallow after the harvest of soybean and maize. The sowing of winter crops, wheat, colza, and barley starts in June, after the second sampling of epilithic biofilms. The median concentrations of atrazine, carbendazim, and imidacloprid, for example, were drastically reduced between the first (spring/summer) and the second (autumn/winter) sampling: 38.0 to $0.5,25.0$ to 4.7 , and 4.1 to $0.5 \mathrm{ng}^{-1}$ of biofilms, respectively (Table 3, statistical analysis is available in appendix Table A5). The concentration of many pesticides in biofilms sampled in autumn/winter was lower than the LD (between 0.5 and $1 \mathrm{ng}^{-1}$ ). The capacity of the epilithic biofilms to biodegrade pesticides is evident and pointed out in various studies (Feckler et al. 2015; Sabater et al. 2007; Staley et al. 2015) that attribute pesticide removal by biofilms to biodegradation, not to sorption. Carles et al. (2019), through a study of exposure of biofilms to glyphosate in mesocosm, were able to define that the biological decomposition of the glyphosate pesticide was performed in approximately 13 days, in the case of low concentration of this pesticide in water $\left(<10 \mu \mathrm{g} \mathrm{L}^{-1}\right)$.

The Guaporé River and its tributaries can be classified as turbulent systems. The area presents a wellpreserved riparian forest, especially in the middle/lower region of the catchment (Table 1). Villeneuve et al. (2010) showed that in turbulent mesocosms, the biofilms were more diversified in comparison to static environments. Additionally, the relation between the autochthonous primary production and the heterotrophic organisms in biofilms is modified with direct exposure of rivers to the sun which may alter the autotrophic/heterotrophic proportion in biofilms (Feckler et al. 2015). Furthermore, the average temperature of the water is also adequate to optimal microbiota development in the winter season $\left(17.9\right.$ and $22.5^{\circ} \mathrm{C}$ in autumn/winter and spring/summer samplings, respectively).

However, the soil is a reservoir of pesticides, and it can transfer the compounds to the surface and groundwater ecosystems (Sassine et al. 2017) slowly and for a long time. For example, in Brazil, the use of the herbicide triazines is authorized $\left(2.5 \times 10^{4} \mathrm{mg}\right.$ of atrazine consumed in 2017 , the fifth most used pesticide), and 

and the continuing legal applications guarantee the flux of pesticides from higher to lower landscape position, and the water can be a constant pesticide source to the biofilms. The carbendazim and imidacloprid persistence in biofilms sampled in July, especially in the upper region of the Guaporé catchment, are probably being used for the control of end-cycle maladies (Cercospora kikuchii and Septoria glycines) and sucking insect pests in soybeans. These pesticides are widely used until a few days before the soybean harvest.

Tien et al. (2013) evaluated the maximum pesticide removal capacity in river biofilms and showed that natural river biofilms from different seasons were able to remove different pesticides with rates ranging from 99.6 to $41.2 \%$. The authors observed different dissipation rates and degradation capacities in biofilms from different seasons which might be due to the colonization of microbial species with different pesticide degradation capacity within river biofilms and might differ with the variation of pesticide concentration in river water associated with the lower use of pesticides in different seasons.

Biofilms as a monitoring tool at a global scale

The use of biofilms as an environmental indicator can be carried out all over the world due to their development in all aquatic ecosystems as part of the trophic network (Aubertheau et al. 2017; Bastos et al. 2018; Fernandes et al. 2019; Huerta et al. 2016). In this study, it was possible to verify that biofilms were able to represent the anthropic pressure near the collection points, even with the use of different pesticides and times of application of agricultural crops, biofilms were able to capture pesticide compounds even in rivers located in areas with low anthropic activity and/or with low concentration of these compounds. In addition, pollution from different soil management systems can be identified through sampling and analysis of biofilms; thus, biofilms can be used as tools to evaluate the health and water quality of water bodies. Furthermore, pesticides are ubiquitous in aquatic environments and constantly interact with aquatic organisms, including those that makeup biofilms at fluctuating concentrations (Chaumet et al. 2019a). The main advantage over point sampling (water sampling) is its capacity to accumulate compounds in an integrative way because of the heterogeneity of biofilm composition, the availability of diverse sorption sites, and their probable saturation may contribute to multiple kinetics of bioaccumulation, being consecutive or staking (Zhang et al. 2018). Chaumet et al. (2019b) studying diuron bioaccumulation in biofilms have demonstrated a phenomenon of continuous diffusion, but it was not linearly correlated with bioaccumulation, highlighting the complex capture mechanisms operating within the 
biofilm matrix. The study of biofilm contamination becomes important as a basis for better exposure assessment of biofilm feeding organisms and as useful for determining the risk of trophic transfer of pesticides along the aquatic food chain. Besides, biofilms develop naturally on several surfaces, such as rock surfaces in riverbeds, not having costs for implementation, like other passive samplers that are expensive and must be installed at sampling points.

\section{Conclusions}

The epilithic biofilms sampled in the Guaporé River watershed bioaccumulated the active principles of 10 herbicides (2,4-D, atrazine, chlorotoluron, simazine, nicosulfuron, mesosulfuron-methyl, mesotrione, prosulfuron, isoproturon, thifensulfuron-methyl), 7 fungicides (boscalid, carbendazim, epoxiconazole, tebuconazole, metconazole, prochloraz, prothioconazole), 2 insecticides (chlorpyrifos and imidacloprid), and 1 metabolite (desethyl-atrazine).

The use of epilithic biofilms as integrative matrix is effective in discriminating the spatial and temporal sources of contamination independent of the physicochemical characteristics of the compounds. Additionally, by employing the detection frequency and median concentrations of pesticides in biofilms, it was possible to estimate in which of the two main cultures (soybean or maize) the pesticides were employed.

The concentrations of the main pesticides monitored were sharply reduced in the epilithic biofilms sampled some months after the application in the summer cultures, showing the high capacity of resilience and detoxification.

\section{References}

Aravinna, P., Priyantha, N., Pitawala, A., \& Yatigammana, S. K. (2017). Use pattern of pesticides and their predicted mobility into shallow groundwater and surface water bodies of paddy lands in Mahaweli river basin in Sri Lanka. Journal of Environmental Science and Health, Part B, 52(1), 37-47. https://doi.org/10.1080/03601234.2016.1229445

Aslam, S., Iqbal, A., Lafolie, F., Recous, S., Benoit, P., \& Garnier, P. (2018). Mulch of plant residues at the soil surface impact the leaching and persistence of pesticides: A modelling study from soil columns. Journal of Contaminant Hydrology, 214, 54-64. https://doi.org/10.1016/j.jconhyd.2018.05.008 
Aubertheau, E., Stalder, T., Mondamert, L., Ploy, M.-C., Dagot, C., \& Labanowski, J. (2017). Impact of

422 wastewater treatment plant discharge on the contamination of river biofilms by pharmaceuticals and antibiotic resistance. Science of The Total Environment, 579, 1387-1398. https://doi.org/10.1016/j.scitotenv.2016.11.136

Barrett, K. A., \& McBride, M. B. (2007). Phosphate and glyphosate mobility in soil columns amended with roundup: Soil Science, 172(1), 17-26. https://doi.org/10.1097/01.ss.0000240549.44551.3d

Bastos, M. C., Rheinheimer dos Santos, D., Monteiro de Castro Lima, J. A., le Guet, T., Santanna dos Santos, M. A., Zanella, R., et al. (2018). Presence of Anthropogenic Markers in Water: A Case Study of the Guaporé River Watershed, Brazil. CLEAN - Soil, Air, Water, 46(3), 1700019. https://doi.org/10.1002/clen.201700019

Battin, T. J., Besemer, K., Bengtsson, M. M., Romani, A. M., \& Packmann, A. I. (2016). The ecology and biogeochemistry of stream biofilms. Nature Reviews Microbiology, 14(4), 251-263. https://doi.org/10.1038/nrmicro.2016.15

Beketov, M. A., Kefford, B. J., Schafer, R. B., \& Liess, M. (2013). Pesticides reduce regional biodiversity of stream invertebrates. Proceedings of the National Academy of Sciences, 110(27), 11039-11043. https://doi.org/10.1073/pnas.1305618110

Bricheux, G., Morin, L., Le Moal, G., Coffe, G., Balestrino, D., Charbonnel, N., et al. (2013). Pyrosequencing assessment of prokaryotic and eukaryotic diversity in biofilm communities from a French river. MicrobiologyOpen, 2(3), 402-414. https://doi.org/10.1002/mbo3.80

Carles, L., Gardon, H., Joseph, L., Sanchís, J., Farré, M., Artigas, J., 2019. Meta-analysis of glyphosate contamination in surface waters and dissipation by biofilms. Environment International 124, 284-293. https://doi.org/10.1016/j.envint.2018.12.064

Chaumet, B., Morin, S., Boutry, S., \& Mazzella, N. (2019a). Diuron sorption isotherms in freshwater biofilms. Science of The Total Environment, 651, 1219-1225. https://doi.org/10.1016/j.scitotenv.2018.09.286

Chaumet, B., Morin, S., Hourtané, O., Artigas, J., Delest, B., Eon, M., \& Mazzella, N. (2019b). Flow conditions influence diuron toxicokinetics and toxicodynamics in freshwater biofilms. Science of The Total Environment, 652, 1242-1251. https://doi.org/10.1016/j.scitotenv.2018.10.265

Deuschle, D., Minella, J. P. G., Hörbe, T. de A. N., Londero, A. L., \& Schneider, F. J. A. (2019a). Erosion and hydrological response in no-tillage subjected to crop rotation intensification in southern Brazil. Geoderma, 340, 157-163. https://doi.org/10.1016/j.geoderma.2019.01.010 
Didoné, E. J., Minella, J. P. G., Reichert, J. M., Merten, G. H., Dalbianco, L., de Barrros, C. A. P., \& Ramon, R. (2014). Impact of no-tillage agricultural systems on sediment yield in two large catchments in Southern Brazil. Journal of Soils and Sediments, 14(7), 1287-1297. https://doi.org/10.1007/s11368-013-0844-6

Edwards, S. J., \& Kjellerup, B. V. (2013). Applications of biofilms in bioremediation and biotransformation of persistent organic pollutants, pharmaceuticals/personal care products, and heavy metals. Applied Microbiology and Biotechnology, 97(23), 9909-9921. https://doi.org/10.1007/s00253-013-5216-z

Essington, M. E. (2005). Soil and water chemistry: an integrative approach. Boca Raton: CRC Press. http://public.eblib.com/choice/publicfullrecord.aspx?p=198638_0. Accessed 12 August 2019

Feckler, Kahlert, M., \& Bundschuh, M. (2015). Impacts of Contaminants on the Ecological Role of Lotic Biofilms | SpringerLink. https://link.springer.com/article/10.1007/s00128-015-1642-1. Accessed 5 August 2019

Fernandes, G., Aparicio, V. C., Bastos, M. C., De Gerónimo, E., Labanowski, J., Prestes, O. D., et al. (2019). Indiscriminate use of glyphosate impregnates river epilithic biofilms in southern Brazil. Science of The Total Environment, 651, 1377-1387. https://doi.org/10.1016/j.scitotenv.2018.09.292

Food and Agriculture Organization of the United Nations, (2018). FAO [WWW Document]. Pesticides - Use per area of cropland. URL http://www.fao.org/faostat/en/\#data/EP/visualize (accessed 10.19.19).

Flemming, H.-C., \& Wingender, J. (2010). The biofilm matrix. Nature Reviews Microbiology, 8(9), $623-633$. https://doi.org/10.1038/nrmicro2415

Graminha, E. B. N., Gonçalves, A. Z. L., Pirota, R. D. P. B., Balsalobre, M. A. A., Da Silva, R., \& Gomes, E. (2008). Enzyme production by solid-state fermentation: Application to animal nutrition. Animal Feed Science and Technology, 144(1-2), 1-22.https://doi.org/10.1016/j.anifeedsci.2007.09.029

Huerta, B., Rodriguez-Mozaz, S., Nannou, C., Nakis, L., Ruhí, A., Acuña, V., et al. (2016). Determination of a broad spectrum of pharmaceuticals and endocrine disruptors in biofilm from a waste water treatment plant-impacted river. Science of The Total Environment, 540, 241-249. https://doi.org/10.1016/j.scitotenv.2015.05.049

IBGE | Portal do IBGE | IBGE. (n.d.). https://ibge.gov.br/. Accessed 29 February 2020

IBAMA - Instituto Brasileiro do Meio Ambiente e dos Recursos Naturais Renováveis. https://www.mma.gov.br/assuntos-internacionais/item/11586-ibama-instituto-brasileiro-do-meioambiente-e-dos-recursos-naturais-renovaveis. Accessed 29 February 2020 
INMET, Banco de Dados Meteorológicos para Ensino e Pesquisa. Instituto Nacional de Meteorologia (2015). [WWW Document]. URL http://www.inmet.gov.br/projetos/rede/pesquisa/ (accessed 10.20.19).

INMET, Banco de Dados Meteorológicos para Ensino e Pesquisa. Instituto Nacional de Meteorologia (2019). [WWW Document]. URL http://Www.inmet.gov.br/projetos/rede/pesquisa/ (accessed 10.20.19).

Jelić, A., Petrović, M., \& Barceló, D. (2009). Multi-residue method for trace level determination of pharmaceuticals in solid samples using pressurized liquid extraction followed by liquid chromatography/quadrupole-linear ion trap mass spectrometry. Talanta, 80(1), 363-371. https://doi.org/10.1016/j.talanta.2009.06.077

Kaiser, D. R., Sequinatto, L., Reinert, D. J., Reichert, J. M., Rheinheimer, D. S., \& Dalbianco, L. (2015). High Nitrogen Fertilization of Tobacco Crop in Headwater Watershed Contaminates Subsurface and Well Waters with Nitrate. Journal of Chemistry, 2015, 1-11. https://doi.org/10.1155/2015/375092

Kim, S. T., Fauvelle, V., Morin, S., \& Mazzella, N. (2016). Improving Toxicity Assessment of Pesticide Mixtures: The Use of Polar Passive Sampling Devices Extracts in Microalgae Toxicity Tests. Frontiers in Microbiology, 7. https://doi.org/10.3389/fmicb.2016.01388

Kleber, M., Sollins, P., \& Sutton, R. (2007). A conceptual model of organo-mineral interactions in soils: selfassembly of organic molecular fragments into zonal structures on mineral surfaces. Biogeochemistry, 85(1), 9-24. https://doi.org/10.1007/s10533-007-9103-5

Lawrence, J. R., Kopf, G., Headley, J. V., \& Neu, T. R. (2001). Sorption and metabolism of selected herbicides in river biofilm communities. Canadian Journal of Microbiology, 47(7), 634-641. https://doi.org/10.1139/cjm-47-7-634

Lewis, K. A., Tzilivakis, J., Warner, D. J., \& Green, A. (2016). An international database for pesticide risk assessments and management. Human and Ecological Risk Assessment: An International Journal, 22(4), 1050-1064. https://doi.org/10.1080/10807039.2015.1133242

Li, K., Xing, B., \& Torello, W. A. (2005). Effect of organic fertilizers derived dissolved organic matter on pesticide sorption and leaching. Environmental pollution (Barking, Essex: 1987), 134(2), 187-194. https://doi.org/10.1016/j.envpol.2004.08.011

Lima, J. A. M. C., Labanowski, J., Bastos, M. C., Zanella, R., Prestes, O. D., de Vargas, J. P. R., et al. (2020). "Modern agriculture" transfers many pesticides to watercourses: a case study of a representative rural catchment of southern Brazil. Environmental Science and Pollution Research. https://doi.org/10.1007/s11356-019-06550-8 
Özkara, A., Aky1l, D., \& Konuk, M. (2016). Pesticides, Environmental Pollution, and Health. Environmental Health Risk - Hazardous Factors to Living Species. https://doi.org/10.5772/63094

Pascual Aguilar, J. A., Andreu, V., Campo, J., Picó, Y., \& Masiá, A. (2017). Pesticide occurrence in the waters of Júcar River, Spain from different farming landscapes. Science of The Total Environment, 607-608, 752-760. https://doi.org/10.1016/j.scitotenv.2017.06.176

Pérez, D. J., Okada, E., De Gerónimo, E., Menone, M. L., Aparicio, V. C., \& Costa, J. L. (2017). Spatial and temporal trends and flow dynamics of glyphosate and other pesticides within an agricultural watershed in Argentina: Spatial-temporal and flow dynamics of pesticides in a basin. Environmental Toxicology and Chemistry, 36(12), 3206-3216. https://doi.org/10.1002/etc.3897

Pesce, S., Bouchez, A., \& Montuelle, B. (2012). Effects of Organic Herbicides on Phototrophic Microbial Communities in Freshwater Ecosystems. In D. M. Whitacre (Ed.), Reviews of Environmental Contamination and Toxicology (Vol. 214, pp. 87-124). New York, NY: Springer New York. https://doi.org/10.1007/978-1-4614-0668-6_5

Proia, L., Lupini, G., Osorio, V., Pérez, S., Barceló, D., Schwartz, T., et al. (2013). Response of biofilm bacterial communities to antibiotic pollutants in a Mediterranean river. Chemosphere, 92(9), 1126-1135. https://doi.org/10.1016/j.chemosphere.2013.01.063

Rhea, D. T., Harper, D. D., Farag, A. M., \& Brumbaugh, W. G. (2006). Biomonitoring in the Boulder River Watershed, Montana, USA: Metal Concentrations in Biofilm and Macroinvertebrates, and Relations with Macroinvertebrate Assemblage. Environmental Monitoring and Assessment, 115(1-3), 381-393. https://doi.org/10.1007/s10661-006-7086-7

Sabater, S., Guasch, H., Ricart, M., Romaní, A., Vidal, G., Klünder, C., \& Schmitt-Jansen, M. (2007). Monitoring the effect of chemicals on biological communities. The biofilm as an interface. Analytical and Bioanalytical Chemistry, 387(4), 1425-1434. https://doi.org/10.1007/s00216-006-1051-8

Sassine, L., Le, C. G. L. S., Khaska, M., Verdoux, P., Meffre, P., Benfodda, Z., \& Roig, B. (2017). Spatial distribution of triazine residues in a shallow alluvial aquifer linked to groundwater residence time. Environmental Science and Pollution Research International, 24(8), 6878-6888. https://doi.org/10.1007/s11356-016-7224-x

Späth, R., Flemming, H.-C., \& Wuertz, S. (1998). Sorption properties of biofilms. Water Science and Technology, 37(4-5), 207-210. https://doi.org/10.2166/wst.1998.0623 
Staley, Z. R., Harwood, V. J., \& Rohr, J. R. (2015). A synthesis of the effects of pesticides on microbial persistence in aquatic ecosystems. Critical Reviews in Toxicology, 45(10), 813-836. https://doi.org/10.3109/10408444.2015.1065471

Tang, G., Yao, J., Zhang, X., Lu, N., \& Zhu, K. Y. (2018). Comparison of gene expression profiles in the aquatic midge (Chironomus tentans) larvae exposed to two major agricultural pesticides. Chemosphere, 194, 745-754. https://doi.org/10.1016/j.chemosphere.2017.12.040

Tiecher, T., Caner, L., Minella, J. P. G., Pellegrini, A., Capoane, V., Rasche, J. W. A., et al. (2017a). Tracing sediment sources in two paired agricultural catchments with different riparian forest and wetland $\begin{array}{lllll}\text { proportion } & \text { in } & \text { southern } & \text { Brazil. } & \text { Geoderma, 225-239. }\end{array}$ https://doi.org/10.1016/j.geoderma.2016.10.008

Tiecher, T., Minella, J. P. G., Caner, L., Evrard, O., Zafar, M., Capoane, V., et al. (2017b). Quantifying land use contributions to suspended sediment in a large cultivated catchment of Southern Brazil (Guaporé River, Rio Grande do Sul). Agriculture, Ecosystems \& Environment, 237, 95-108. https://doi.org/10.1016/j.agee.2016.12.004

Tiecher, T., Minella, J. P. G., Evrard, O., Caner, L., Merten, G. H., Capoane, V., et al. (2018). Fingerprinting sediment sources in a large agricultural catchment under no-tillage in Southern Brazil (Conceição River). Land Degradation \& Development, 29(4), 939-951. https://doi.org/10.1002/ldr.2917

Tien, C.-J., Lin, M.-C., Chiu, W.-H., \& Chen, C. S. (2013). Biodegradation of carbamate pesticides by natural river biofilms in different seasons and their effects on biofilm community structure. Environmental Pollution, 179, 95-104. https://doi.org/10.1016/j.envpol.2013.04.009

Villeneuve, A., Montuelle, B., \& Bouchez, A. (2010). Influence of slight differences in environmental conditions (light, hydrodynamics) on the structure and function of periphyton. Aquatic Sciences, 72(1), 33-44. https://doi.org/10.1007/s00027-009-0108-0

Vymazal, J., \& Březinová, T. (2015). The use of constructed wetlands for removal of pesticides from agricultural runoff and drainage: A review. Environment International, 75, 11-20. https://doi.org/10.1016/j.envint.2014.10.026

Vryzas, Z. (2018). Pesticide fate in soil-sediment-water environment in relation to contamination preventing actions. Current Opinion in Environmental Science \& Health, 4, 5-9. https://doi.org/10.1016/j.coesh.2018.03.001 
568 Zafar, M., Tiecher, T., de Castro Lima, J. A. M., Schaefer, G. L., Santanna, M. A., \& dos Santos, D. R. (2016).

569 Phosphorus seasonal sorption-desorption kinetics in suspended sediment in response to land use and 570 management in the Guaporé catchment, Southern Brazil. Environmental Monitoring and Assessment, 571 188(11), 643. https://doi.org/10.1007/s10661-016-5650-3

572 Zhang, W., Tang, X.-Y., Xian, Q.-S., Weisbrod, N., Yang, J. E., \& Wang, H.-L. (2016). A field study of colloid 573 transport in surface and subsurface flows. Journal of Hydrology, 542, 101-114. https://doi.org/10.1016/j.jhydrol.2016.08.056

575 Zhang, L., Dong, D., Hua, X., \& Guo, Z. (2018). Inhibitory effects of extracellular polymeric substances on 576 ofloxacin sorption by natural biofilms. Science of The Total Environment, 625, 178-184. https://doi.org/10.1016/j.scitotenv.2017.12.271

578

579 